\title{
CORRECTION
}

\section{Correction to: Physiological interventions in cardiac arrest: passing the pilot phase}

\author{
Niklas Nielsen ${ }^{1 *}$, Alain Cariou ${ }^{2,3}$ and Christian Hassager ${ }^{4}$
}

(C) 2019 The Author(s)

\section{Correction to: Intensive Care Med https://doi.org/10.1007/s00134-018-5492-2}

The reference list of the originally published article was incorrect, and now the article has been appropriately modified and updated to reflect the correction information. We apologize for the inconvenience.

The damaging processes leading to a poor outcome after cardiac arrest start at the onset of ischemia and continues during the reperfusion phase. Intensive care treatment in resuscitated patients relies on organ support restoring normal physiology with attention to brain protection. Drugs have not proven beneficial in randomised trials. To date induced hypothermia, or targeted temperature management (TTM), is the only specific intervention implemented in clinical practice. Nevertheless, its final role and configuration is still under debate and currently investigated.

Easily modifiable clinical physiological and metabolic parameters could be ideal treatment candidates to possibly attenuate brain damage. In a pilot trial, strict glucose control was tested versus standard care with no significant difference in the outcome and the concept has not been further challenged [1]. In recent years three possible physiological candidates have been investigated in several observational cohorts indicating better outcome with higher mean arterial pressure (MAP), moderately elevated partial pressure of oxygen $\left(\mathrm{PaO}_{2}\right)$ and mildly elevated partial pressure of carbon dioxide $\left(\mathrm{PaCO}_{2}\right)[2$,

\footnotetext{
*Correspondence: niklas.nielsen@telia.com

${ }^{1}$ Department of Clinical Sciences Lund, Anesthesia and Intensive Care,

Lund University, Helsingborg Hospital, Lund, Sweden

Full author information is available at the end of the article
}

The original article can be found online at https://doi.org/10.1007/s0013 4-018-5492-2.
3]. Other reports have indicated worse outcome with increasing doses of vasopressors, hypotension, hypocapnia, severe hypercapnia and severe hyperoxia [4-6]. Also, completely neutral reports have been published [7]. A pilot trial of mild hypercapnia versus normocapnia (standard care) suggested better outcome and lower levels of biomarkers of brain damage with mildly elevated carbon dioxide levels [8]. The well-known limitations of observational inferences have called for randomised trials.

In this issue of ICM a Finnish/Danish group has, in two publications, reported an elegant 2 by 3 factorial multicentre pilot trial in 123 comatose cardiac arrest patients - the COMACARE-trial $[9,10]$. The patients were randomised to one of eight groups with either high or low normal MAP, high or low normal $\mathrm{PaCO}_{2}$ and normal or moderately elevated $\mathrm{PaO}_{2}$. Being a pilot trial feasibility was an important outcome and the authors demonstrated clear and distinct separation between the groups for $\mathrm{MAP}, \mathrm{PaO}_{2}$ and $\mathrm{PaCO}_{2}$. The primary effect outcome was serum level of neuron specific enolase (NSE) at $48 \mathrm{~h}$ after the arrest, a time-point where this prognostic biomarker of brain damage separates good from poor outcome. Interestingly there were no detectable differences in 48-h-NSE for any of the three interventions, and secondary outcomes such as NSE over time, the biomarker S100B, cardiac troponin, global electroencephalographic pattern, survival and functional outcome at 6 months were also neutral. The overall outcome was strikingly good for a cardiac arrest cohort and it is worth emphasizing that the patient group was positively selected in terms of age, initial rhythm and a presumed cardiac cause of the arrest. The single statistically significant finding was higher cerebral oxygen saturation, up to approximately $10 \%$ absolute difference, with higher levels for high normal $\mathrm{PaO}_{2}$ and $\mathrm{PaCO}_{2}$ and with the figures suggesting more difference for $\mathrm{PaCO}_{2}$ than $\mathrm{PaO}_{2}$. Vasodilation due 
to elevated $\mathrm{PaCO}_{2}$ and increased cerebral blood flow (CBF) may thus be more powerful in terms of increasing oxygen delivery with the chosen intervention targets. In this trial CBF was however not measured and its correlation to regional cerebral saturation is not fully elucidated. Since oxygen content typically increases marginally between 10 and $25 \mathrm{kPa}$ and the content of oxygen in blood is more influential on CBF than $\mathrm{PaO}_{2}$ it is reasonable not to expect a tremendous effect on $\mathrm{CBF}$ or cerebral saturation with the oxygen intervention in this trial [11]. Importantly the changes in cerebral saturation was not translated to any other outcome differences. Higher MAP did not influence cerebral saturation (or any other outcome), perhaps due to an adequate cerebral perfusion pressure obtained already at the low normal level of MAP. In contrast, a recent randomized trial, presented at American Heart Association 2018, did report that a higher target MAP (85-100 mmHg) improved cerebral perfusion and oxygenation. Signs of anoxic brain damage on magnetic resonance imaging and functional outcome were however neutral.

NSE has been used as a surrogate outcome in several cardiac arrest trials as it a good discriminator of poor and good outcome [12]. A considerable drawback with NSE is the sensitivity to hemolysis, due to leakage of NSE from red blood cells [13]. The authors report that seven analyses were excluded due to hemolysis and only one sample at the 48-h-primary outcome. However, hemolysis was only analysed in one of the participating countries and the cut-off level for exclusion due to hemolysis was very high (>500 mg free haemoglobin/L). Already $300 \mathrm{mg} / \mathrm{L}$ is considered visible hemolysis and NSE levels are heavily influenced at much lower degree and dependent on the relation NSE/hemolysis [14]. With lower serum levels of NSE little hemolysis can be tolerated, while with higher levels more hemolysis is tolerated. With the in median modest levels of NSE reported in this trial a much lower cut-off level for exclusion due to hemolysis should have been employed, and significant hemolysis was therefore likely higher than reported. The influence on the trial results are difficult to appreciate. Reassuringly, NSE findings were in line with all other outcomes and the levels were not used for prognostication but for comparison between groups. For future trials, other biomarkers such as protein-tau or neurofilament, not or less sensitive to hemolysis, may prove better surrogate outcomes [15].

Common critique of clinical trials includes questions of timing and dose of the intervention. In this trial the interventions were introduced immediately after emergency randomisation with deferred consent, and in light of other trials manipulating oxygen levels in the ambulance having problems with hypoxia [16], that airways often not are secured prior to hospital admission, and that the initial phase after return of spontaneous circulation seldom allows for fine tuning of hemodynamics, the $3 \mathrm{~h}$ median delay seem difficult to shorten and likely will reflect clinical practice if any of the interventions be implemented. The authors designed the trial elegantly, randomising to extremes of normal levels for two of the three target interventions, and thus most of the patients were treated within standard care. Although statistically different, the interventions may thus have been too little separated to produce meaningful clinical difference. Also, the trial was indeed a pilot with a very optimistic predefined power calculation (50\% reduction of NSE) and a larger trial may very well have indicated more robust signals. The main and important conclusion of the COMACARE-trial must be that the targets readily can be obtained for all three interventions and that adequately powered trials may follow, where carbon dioxide manipulation possibly have the most intriguing physiological rationale.

\section{Author details \\ ${ }^{1}$ Department of Clinical Sciences Lund, Anesthesia and Intensive Care, Lund University, Helsingborg Hospital, Lund, Sweden. ${ }^{2}$ Medical Intensive Care Unit, AP-HP, Cochin Hospital, Paris, France. ${ }^{3}$ Paris Descartes University, Paris, France. ${ }^{4}$ Departments of Cardiology and Clinical Medicine, Rigshospitalet, University of Copenhagen, Copenhagen, Denmark.}

\section{Publisher's Note}

Springer Nature remains neutral with regard to jurisdictional claims in published maps and institutional affiliations.

Published online: 17 January 2019

\section{References}

1. Oksanen T, Skrifvars MB, Varpula T, Kuitunen A, Pettila V, Nurmi J, Castren $M$ (2007) Strict versus moderate glucose control after resuscitation from ventricular fibrillation. Intensive Care Med 33:2093-2100

2. Elmer J, Scutella M, Pullalarevu R, Wang B, Vaghasia N, Trzeciak S, RosarioRivera BL, Guyette FX, Rittenberger JC, Dezfulian C, Pittsburgh PostCardiac Arrest S (2015) The association between hyperoxia and patient outcomes after cardiac arrest: analysis of a high-resolution database. Intensive Care Med 41:49-57

3. Vaahersalo J, Bendel S, Reinikainen M, Kurola J, Tiainen M, Raj R, Pettila V, Varpula T, Skrifvars MB, Group FS (2014) Arterial blood gas tensions after resuscitation from out-of-hospital cardiac arrest: associations with longterm neurologic outcome. Crit Care Med 42:1463-1470

4. Bro-Jeppesen J, Annborn M, Hassager C, Wise MP, Pelosi P, Nielsen N, Erlinge D, Wanscher M, Friberg H, Kjaergaard J, Investigators TTM (2015) Hemodynamics and vasopressor support during targeted temperature management at 33 degrees $C$ versus 36 degrees $C$ after out-of-hospital cardiac arrest: a post hoc study of the target temperature management trial. Crit Care Med 43:318-327

5. McKenzie N, Williams TA, Tohira H, Ho KM, Finn J (2017) A systematic review and meta-analysis of the association between arterial carbon dioxide tension and outcomes after cardiac arrest. Resuscitation 111:116-126

6. Roberts BW, Kilgannon JH, Hunter BR, Puskarich MA, Pierce L, Donnino M, Leary M, Kline JA, Jones AE, Shapiro NI, Abella BS, Trzeciak S (2018) Association between early hyperoxia exposure after resuscitation from cardiac 
arrest and neurological disability: prospective multicenter protocoldirected cohort study. Circulation 137:2114-2124

7. Ebner F, Harmon MBA, Aneman A, Cronberg T, Friberg H, Hassager C, Juffermans N, Kjaergaard J, Kuiper M, Mattsson N, Pelosi P, Ullen S, Unden J, Wise MP, Nielsen N (2018) Carbon dioxide dynamics in relation to neurological outcome in resuscitated out-of-hospital cardiac arrest patients: an exploratory Target Temperature Management Trial substudy. Crit Care 22:196

8. Eastwood GM, Schneider AG, Suzuki S, Peck L, Young H, Tanaka A, Martensson J, Warrillow S, McGuinness S, Parke R, Gilder E, McCarthy L, Galt P, Taori G, Eliott S, Lamac T, Bailey M, Harley N, Barge D, Hodgson CL, Morganti-Kossmann MC, Pebay A, Conquest A, Archer JS, Bernard S, Stub D, Hart GK, Bellomo R (2016) Targeted therapeutic mild hypercapnia after cardiac arrest: a phase II multi-centre randomised controlled trial (the CCC trial). Resuscitation 104:83-90

9. Jakkula P, Pettilä V, Skrifvars MB, Hästbacka J, Loisa P, Tiainen M, Wilkman E, Toppila J, Koskue T, Bendel S, Birkelund T, Laru-Sompa R, Valkonen M, Reinikainen M, COMACARE Study Group (2018) Targeting low-normal or high-normal mean arterial pressure after cardiac arrest and resuscitation: a randomised pilot trial. Intensive Care Med 44:2091-2101

10. Jakkula P, Reinikainen M, Hästbacka J, Loisa P, Tiainen M, Pettilä V, Toppila J, Lähde M, Bäcklund M, Okkonen M, Bendel S, Birkelund T, Pulkkinen A, Heinonen J, Tikka T, Skrifvars MB, COMACARE Study Group (2018) Targeting two different levels of both arterial carbon dioxide and arterial oxygen after cardiac arrest and resuscitation: a randomised pilot trial. Intensive Care Med 44:2112-2121

11. Johnston AJ, Steiner LA, Gupta AK, Menon DK (2003) Cerebral oxygen vasoreactivity and cerebral tissue oxygen reactivity. Br J Anaesth 90:774-786
12. Stammet $P$, Collignon $\mathrm{O}$, Hassager $C$, Wise MP, Hovdenes J, Aneman $A$, Horn J, Devaux Y, Erlinge D, Kjaergaard J, Gasche Y, Wanscher M, Cronberg T, Friberg H, Wetterslev J, Pellis T, Kuiper M, Gilson G, Nielsen N, Investigators TT-T (2015) Neuron-specific enolase as a predictor of death or poor neurological outcome after out-of-hospital cardiac arrest and targeted temperature management at 33 degrees $C$ and 36 degrees $C$. J Am Coll Cardiol 65:2104-2114

13. Ramont L, Thoannes H, Volondat A, Chastang F, Millet MC, Maquart FX (2005) Effects of hemolysis and storage condition on neuron-specific enolase (NSE) in cerebrospinal fluid and serum: implications in clinical practice. Clin Chem Lab Med 43:1215-1217

14. Petinos P, Gay S, BadrickT (2015) Variation in laboratory reporting of haemolysis-a need for harmonisation. Clin Biochem Rev 36:133-137

15. Moseby-Knappe M, Mattsson N, Nielsen N, Zetterberg H, Blennow K, Dankiewicz J, Dragancea I, Friberg H, Lilja G, Insel PS, Rylander C, Westhall E, Kjaergaard J, Wise MP, Hassager C, Kuiper MA, Stammet P, Wanscher MCJ, Wetterslev J, Erlinge D, Horn J, Pellis T, Cronberg T (2018) Serum neurofilament light chain for prognosis of outcome after cardiac arrest. JAMA Neurol. https://doi.org/10.1001/jamaneurol.2018.3223

16. Young P, Bailey M, Bellomo R, Bernard S, Dicker B, Freebairn R, Henderson S, Mackle D, McArthur C, McGuinness S, Smith T, Swain A, Weatherall M, Beasley R (2014) HyperOxic Therapy OR NormOxic Therapy after out-ofhospital cardiac arrest (HOT OR NOT): a randomised controlled feasibility trial. Resuscitation 85:1686-1691 